\title{
Environmental Toxicity and Antimicrobial Efficiency of Titanium Dioxide Nanoparticles in Suspension
}

\author{
Muriel Bonnet ${ }^{1}$, Christophe Massard ${ }^{2}$, Philippe Veisseire ${ }^{1}$, Olivier Camares ${ }^{1}$, \\ Komla Oscar Awitor ${ }^{2}$ \\ ${ }^{1}$ Clermont Université, Université d'Auvergne, Laboratoire de Biologie, Aurillac Cedex, France \\ ${ }^{2}$ Clermont Université, Université d'Auvergne, C-BIOSENSS, Clermont-Ferrand Cedex, France \\ Email: muriel.bonnet@udamail.fr
}

Received 4 May 2015; accepted 13 July 2015; published 17 July 2015

Copyright (C) 2015 by authors and Scientific Research Publishing Inc.

This work is licensed under the Creative Commons Attribution International License (CC BY). http://creativecommons.org/licenses/by/4.0/

(c) () Open Access

\section{Abstract}

The aim of this work was to evaluate the photokilling efficiency of synthesized titanium dioxide nanoparticles in suspension. Two strains of Escherichia coli, Lactobacillus casei rhamnosus and Staphylococcus aureus were used as probes to test the photokilling activities of the nanoparticles. The toxicity effects of $\mathrm{TiO}_{2}$ nanoparticles on the environment were determined by a standard test using gram-negative bioluminescent bacteria Vibrio fischeri. The antimicrobial activity of these nanoparticles (NPs) was then investigated versus NPs concentration, UV irradiation time and micro-organism strains. We evaluated the LC50 values of the nanoparticles suspension by counting the Colony-Forming Units. Results highlighted the differences in bacteria sensitivity facing photokilling treatment induced by the irradiation of anatase $\mathrm{TiO}_{2}$ nanoparticles suspension. At the concentration of $1 \mathrm{~g} \cdot \mathrm{L}^{-1} \mathrm{TiO}_{2}$, tested bacteria were killed after 30 minutes of photo-treatment. Using different $\mathrm{TiO}_{2}$ concentrations, the Staphylococcus aureus gram-positive/catalase-positive bacteria were more resistant than gram-negative/catalase-positive ones or gram-positive/catalase-negative bacteria. An effect of UV irradiation was evaluated by the quantification of hydrogen peroxide generated by the photolysis of water molecules in presence of the nanoparticles with or without the most resistant bacterium (S. aureus). After 30 minutes with UV irradiation in these two conditions, the concentration of hydrogen peroxide was $35 \mu \mathrm{M}$ in presence of $1.2 \mathrm{~g} \cdot \mathrm{L}^{-1} \mathrm{TiO}_{2}$ suspension. This result suggested that the resistance mechanism of $S$. aureus was not due to an extracelullar $\mathrm{H}_{2} \mathrm{O}_{2}$ enzymatic degradation.

\section{Keywords}

Photokilling Activity, Titanium Nanoparticles, E. coli, L. c. rhamnosus, S. aureus, Hydrogen Peroxide

How to cite this paper: Bonnet, M., Massard, C., Veisseire, P., Camares, O. and Awitor, K.O. (2015) Environmental Toxicity and Antimicrobial Efficiency of Titanium Dioxide Nanoparticles in Suspension. Journal of Biomaterials and Nanobiotechnology, 6, 213-224. http://dx.doi.org/10.4236/ibnb.2015.63020 


\section{Introduction}

Photokilling of pathogen species is a promising alternative compared to conventional disinfection process. In particular, when chemical cleaning products are not effective or dangerous, a disinfection protocol based on the irradiation of photoactive species can be interesting. Contrary to other cleaning treatments, such as chlorination [1] [2] and ozonation [3]-[5], less toxic by-products are generated and the process can remain effective for a long time. The photokilling disinfection is mainly based on photoinduced oxidative reactions. Among all the photoactives species, $\mathrm{TiO}_{2}$ anatase is widely studied [6] [7] under UV irradiation. The use of photoactive titanium opens the way to the development of self-cleaning materials [8]-[11]. Works have been done to improve the process, concerning the antimicrobial selectivity. Nanocomposite materials with magnetic nanoparticles [12] have been used to enhance the photoactivity of silver/titanium oxide [13] [14]. Within environmental toxicity assessments, the supervising of the effects of nanoparticles on micro-organisms is still very limited. The bioluminescence test Microtox ${ }^{\circledR}$ is often chosen as the first test in a test battery based on speed and cost consideration [15]. It is a standardized toxicity test (AFNOR T90-320, EN ISO 11348-3) system which is also sensitive and reproducible. It is recognized and used throughout the world as a standard test for aquatic toxicity testing [16] to determine EC50 (half maximal Effective Concentration). The photoinactivation of bacteria is a complex and multifaceted phenomenon. Currently many factors are taken into consideration regarding $\mathrm{TiO}_{2}$ nanoparticles toxicity. According to Cai et al. [17], the bactericidal activity of $\mathrm{TiO}_{2} \mathrm{NPs}$, in the presence of UV light, was due to oxidative stress. Gogniat et al. [18] suggested a sequence of nanoparticle interactions with the cell membrane followed by cell membrane oxidation facilitated by Reactive Oxygen Species (ROS). Accordingly, many studies have attributed to ROS production, the nanoparticles bactericidal effect generated under UV light [19] [20]. Furthermore, recent reports have shown that $\mathrm{TiO}_{2}$ nanoparticles can induce the oxidative stress defense of the cell against endogenous ROS like $\mathrm{H}_{2} \mathrm{O}_{2}$, which can sequentially elicit lipids, proteins and DNA damage [21][23]. Many studies also investigated the possibility of nanoparticle penetration inside the bacterial cell membrane as a possible toxicity mechanism [24] [25]. The cell is surrounded by the plasma membrane, a lipid bilayer which contains opposing monolayers, or leaflets, of phospholipids with the hydrophilic head groups facing the extracellular and intracellular solutions, and the hydrophobic tails facing each other. Generally three routes for nanoparticle entry into cells exist: diffusion, endocytosis and channel implication [26]-[28]. When entering the cell, nanoparticles can probably produce intracellular $\mathrm{H}_{2} \mathrm{O}_{2}$. Cells naturally produce this metabolite. This is the reason why a specific mechanism exists to counteract the presence of hydrogen peroxide for detoxifying the cell. Catalase is a tetrameric heme-containing enzyme, and is one of the key antioxidant enzymes present in almost every aerobic organisms, catalyzing the breakdown of hydrogen peroxide to water and molecular oxygen to protect cells against the toxic effects of hydrogen peroxide [29].

In this study, we synthesized an original and stable anatase-crystallized suspension of $\mathrm{TiO}_{2}$ nanoparticles. Escherichia coli strains LE392 and ETEC H10407 (gram-negative/catalase-positive bacteria), Lactobacillus casei rhamnosus strain Lcr35 ${ }^{\circledR}$ (gram-positive/catalase-negative bacteria) and Staphylococcus aureus (SA51, gram-positive/catalase-positive bacteria) were used as probes to test the photokilling efficiency of the nanoparticles in suspension. In particular, the resistance behaviour of different bacteria strains was evaluated using LC50 tests, focusing on two different parameters: the bacteria wall thickness (gram+ or gram-) and the presence or absence of the catalase gene (catalase + or catalase-). Bioluminescent tests were performed to investigate the environmental toxicity of $\mathrm{TiO}_{2}$ in suspension. The quantification of $\mathrm{H}_{2} \mathrm{O}_{2}$ allowed a better understanding of the inactivation mechanism involved in the photokilling process.

\section{Material and Methods}

\subsection{Synthesis of the Nanoparticles Suspension}

The precursor solution was $10 \mathrm{~mL}$ titanium IV isopropoxide supplied by Sigma Aldrich mixed with $10 \mathrm{~mL}$ of anhydrous isopropanol (from Sigma) using a magnetic stirrer at $300 \mathrm{rpm}$. The titanium alkoxide reactivity was lowered by the use of acetylaceton. The spontaneous hydrolysis of the titanium isopropoxide was obtained by the quick addition of $75 \mathrm{~mL}$ of acidified water. The reacting medium was then heated to $100^{\circ} \mathrm{C}$ under reflux for almost 8 hours (peptidization process). After this step, the dispersion was cooled down to room temperature, approximately $20^{\circ} \mathrm{C}$. A clear, yellow, anatase crystallized nanoparticles suspension was obtained, and stored in the dark. 


\subsection{Transmission Electron Microscopy}

The morphology and the particle sizes were characterized using a Philips CM 20 transmission electron microscope (TEM). The accelerating voltage was $200 \mathrm{kV}$. The samples were dispersed in methanol by ultrasonication. A drop of the suspension was then laid on a carbon-coated grid and dried. Selected Area Electron Diffraction (SAED) was performed to determine the crystalinity of the structure. The interplanar spacings were evaluated from the SAED patterns using the following formula:

$$
\lambda L=R d
$$

where $\lambda L$ is the constant of the microscope, $R$ is the ring radius, and $d$ is the interplanar spacing. The constant of the microscope was calculated by measuring the radius of a gold standard pattern whose interplanar spacings were well documented in scientific publications [30].

\subsection{Bacterial Culture}

Four micro-organisms were used for photokilling experiments: Escherichia coli LE392, Enterotoxigenic Escherichia coli H10407, Lactobacillus casei rhamnosus Lcr $35^{\circledR}$ and Staphylococcus aureus (SA51). These bacteria have a size comprised between 0.5 and $5 \mu \mathrm{m}$. E. coli cells were cultured at $37^{\circ} \mathrm{C}$ for $24 \mathrm{~h}$ in Nutrient Broth medium at $\mathrm{pH} 7.2$ (Biokar diagnostics) containing Tryptone $\left(10 \mathrm{~g} \cdot \mathrm{L}^{-1}\right)$, Meat extract $\left(5 \mathrm{~g} \cdot \mathrm{L}^{-1}\right)$ and Sodium Chloride $\left(5 \mathrm{~g} \cdot \mathrm{L}^{-1}\right)$ after $12 \mathrm{~h}$ of pre-culture in the same conditions. Lactobacillus casei rhamnosus Lcr35 ${ }^{\circledR}$ was cultured in De Man, Rogosa, Sharpe (MRS) medium (Bio-Rad, Mitry Mory, France) and S. aureus in Brain Heart Broth (Brain Heart Infusion $17.5 \mathrm{~g} \cdot \mathrm{L}^{-1}$, Pancreatic digest of gelatin $10 \mathrm{~g} \cdot \mathrm{L}^{-1}$, Sodium Chloride $5 \mathrm{~g} \cdot \mathrm{L}^{-1}$, Disodium phosphate $2.5 \mathrm{~g} \cdot \mathrm{L}^{-1}$, Glucose $2 \mathrm{~g} \cdot \mathrm{L}^{-1}$, Biokar diagnostics) under the same conditions than $E$. coli strains. Cells were centrifuged at $2500 \mathrm{~g}$ for $15 \mathrm{~min}$ at $4^{\circ} \mathrm{C}$ and the pellet was re-suspended in de-ionized water to prevent unintentional increase in cell numbers. The initial population of bacteria was determined by enumeration with a Petroff-Hausser Counting Chamber.

\subsection{Bioluminescent Tests}

The Microtox ${ }^{\circledR}$ Procedure employs the bioluminescent marine gram-negative bacterium Vibrio fischeri as test organism. The bacteria are exposed to a range of concentration of the $\mathrm{TiO}_{2}$ in suspension being tested. The reduction in intensity of light emitted from the bacteria is measured along with standard solutions and control samples. Toxicity is, then, inversely proportional to the intensity of the light emitted after contact with the toxic substances. The change in light output and concentration of the toxicant produce a dose/response relationship. The results are normalized and the EC50 (concentration producing a 50\% reduction in light) is calculated.

The basic test protocol (consisting of four test dilutions) was carried out to evaluate the ecotoxicity of the medium containing $\mathrm{TiO}_{2}$ nanoparticles. All tests were performed using the Microtox 500 Analyser, and bioluminescence measurements were monitored at 0,5 and $15 \mathrm{~min}$ of exposure. The effective concentrations causing $50 \%$ of bioluminescence inhibition were computed using the software for Microtox Omni Azur (AZUR environmental, 1998). Toxicity tests were performed in triplicate each week during a two months period and the results are expressed in $\mathrm{mg} \cdot \mathrm{L}^{-1}$.

\subsection{Inactivation Kinetics Measurements and LC50 Tests}

For inactivation kinetics measurements, an amount of $20 \mathrm{~mL}$ of de-ionized water was inoculated with Escherichia coli LE392 or Enterotoxigenic Escherichia coli H10407 suspension in order to achieve a concentration of $10^{6} \mathrm{CFU} \cdot \mathrm{mL}^{-1}$ (Colony-Forming Unit by $\mathrm{mL}$ ). This suspension was placed in a Petri plate with $\mathrm{TiO}_{2}$ nanoparticles to achieve a final concentration in $\mathrm{TiO}_{2}$ of $1 \mathrm{~g} \cdot \mathrm{L}^{-1}$. The slurries were continuously mixed and irradiated with UV (polychromatic fluorescent UV lamps (@Philips TLD $8 \mathrm{~W}$ ) providing a total power of $48 \mathrm{~W}$, in a configuration delivering $1.5 \mathrm{~mW} \cdot \mathrm{cm}^{-2}$ at the liquid surface). A complete mixing was done with a sterilized Teflon magnetic stir bar placed in the Petri dish with a speed of $200 \mathrm{rpm}$.

Sampling of the solutions was done at requisite time intervals (from 0 to $30 \mathrm{~min}$ ) by pipetting $1 \mathrm{~mL}$ from the suspension and serially diluted in $9 \mathrm{~mL}$ of Ringer's solution. After sufficient mixing, $100 \mu \mathrm{L}$ aliquots of each dilution were plated onto solid Nutrient Gelose medium (Biokar diagnostics) with agar $15 \mathrm{~g} \cdot \mathrm{L}^{-1}$. Colony-Forming Units were counted after overnight incubation at $37^{\circ} \mathrm{C}$. All experiments were made in aseptic conditions to pre- 
vent any contamination in the media. The counts from three independent experiments corresponding to a particular sample were averaged. The method used for the $\mathrm{LC}_{50}$ tests was similar to that used for inactivation kinetics and was performed on all bacteria strains with nanoparticles concentrations from 50 to $1200 \mathrm{mg} \cdot \mathrm{L}^{-1} \mathrm{TiO}_{2}$ under $30 \mathrm{~min} \mathrm{UV}$ irradiation at $1.5 \mathrm{~mW} \cdot \mathrm{cm}^{-2}$.

\subsection{Hydrogen Peroxide Concentration Determination}

Generation of hydrogen peroxide by $\mathrm{TiO}_{2}$ nanoparticules in an aqueous liquid suspension was determined as described by Batdorj et al. [31] with slight modifications. Aqueous solutions of $\mathrm{TiO}_{2}$ particles concentrations ranging from 0 to $1200 \mathrm{mg} \cdot \mathrm{L}^{-1}$ were placed in Petri plates and continuously mixed in the dark or irradiated with UV for 30 minutes. $\mathrm{H}_{2} \mathrm{O}_{2}$ concentrations were measured after eliminating the nanoparticles by centrifugation for $15 \mathrm{~min}$ at $200000 \mathrm{~g}$. One $\mathrm{mL}$ of supernatant was added to a solution containing $100 \mu \mathrm{l}$ of 4-aminoantipyrine (4 $\mathrm{mg} \cdot \mathrm{mL}^{-1}$ solution of 4-amino-2, 3-dimethyl-1-phenyl-3-pyrazolin-5-one, Sigma), $40 \mu \mathrm{l}$ of water-satured phenol, $60 \mu \mathrm{l}$ of horseradish peroxidase type VI-A (Sigma, $500 \mathrm{U} \cdot \mathrm{mL}^{-1}$ solution in sodium phosphate buffer $\mathrm{pH}$ 6) and $800 \mu \mathrm{l}$ of phosphate buffer $\mathrm{Na}_{2} \mathrm{HPO}_{4} / \mathrm{NaH}_{2} \mathrm{PO}_{4}(0.1 \mathrm{M}$, pH 7). The reaction was allowed to proceed for 5 min and the absorbance was measured at $505 \mathrm{~nm}$. The hydrogen peroxide was quantified using a standard curve performed with concentrations ranging from 10 to $200 \mu \mathrm{M}$.

\section{Results and Discussion}

\subsection{Nanoparticles Suspension Synthesis}

Stable titanium dioxide nanoparticles in suspension are fabricated using a derivate sol gel process. Figure 1 shows the main steps of the synthesis protocol. This soft chemistry process is a one-pot, low temperature and efficient method to obtain highly dispersed colloids in a carrying liquid. The first step consists in the chelation of the titanium isopropoxide with an organic ligand, acetylacetone. This reaction is a substitution of alkoxy group of the titanium alcoxyd molecular species by beta diketone ligands. In consequence, the hydrolysis kinetic of the titanium precursor is lowered and undesirable precipitation avoided. Hydrolysis-condensation reactions were carried out by dropping acidified water in the homogeneous medium previously diluted in some isopropylic alcohol. The reacting mixture was heated under reflux for almost 8 hours to obtain a stable dispersion of $\mathrm{TiO}_{2}$

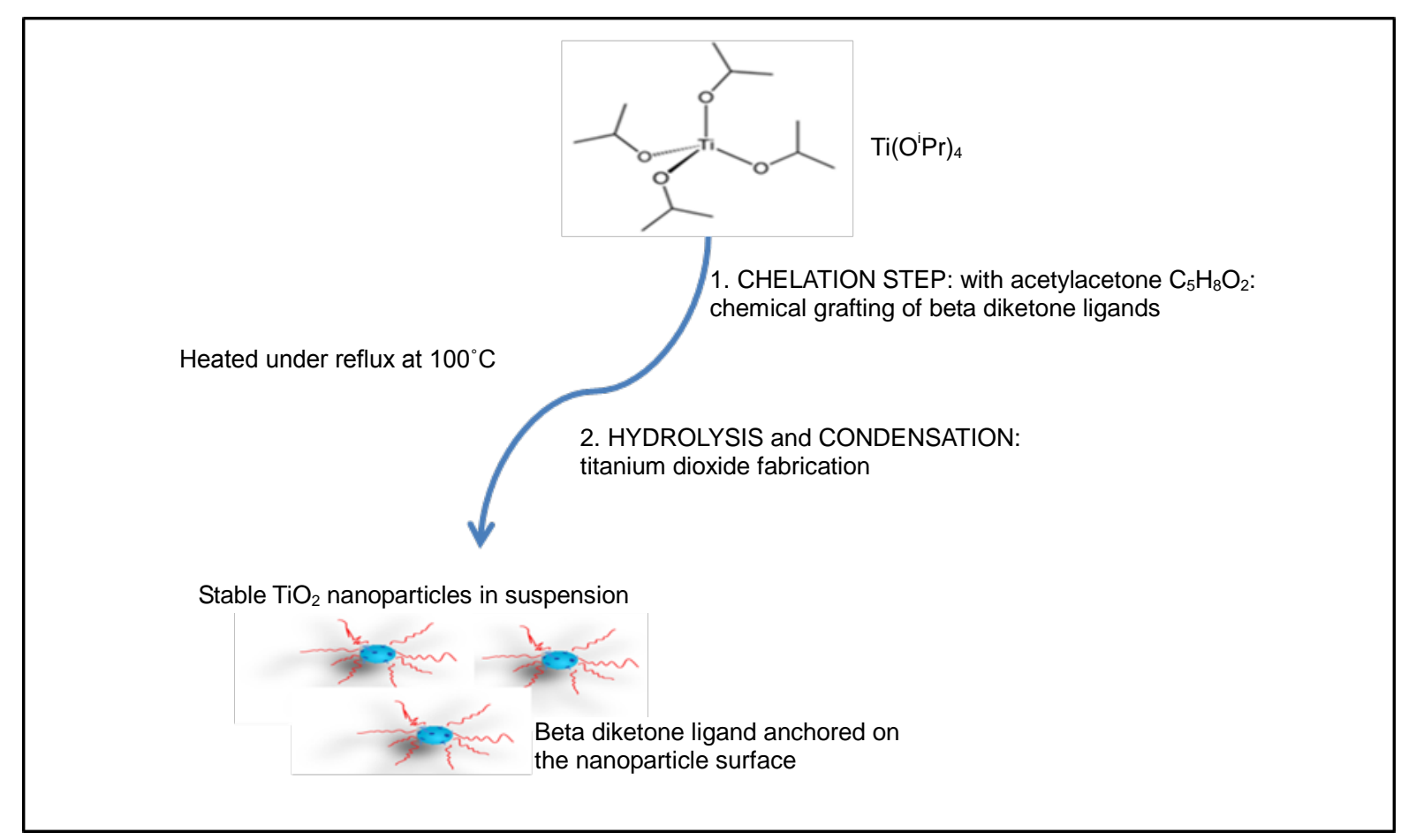

Figure 1. Main steps of the synthesis of homogeneous suspension of $\mathrm{TiO}_{2}$ nanoparticles in an aqueous medium. 
nanoparticles in an aqueous liquid. Taking into account that the $\mathrm{pH}$ of liquid carrier is low, the $\mathrm{TiO}_{2}$ mineral oxide nanoparticles have a positive surface charge.

\subsection{Transmission Electron Microscopy}

A TEM picture and the associated SAED pattern of our as-synthesized sample are presented in Figure 2. The TEM image (Figure 2(a)) shows that most of the particles are elongated, some of them are spherical. From these TEM pictures, the mean crystallite diameter is approximately 8 nanometers.

The SAED patterns of the most intense spots are shown in Figure 2(b). The comparison, in Table 1, between the interplanar distances calculated from the SAED patterns and the tabulated ones obtained for the anatase crystallographic structure exhibits a good agreement and confirms the anatase crystalline structure of our synthesized sample.

\subsection{Bioluminescent Tests}

The Microtox ${ }^{\circledR}$ test has been routinely applied to treated waste waters or single compounds and mixtures of inorganic and organic compounds [32]. Furthermore, bioluminescence test becomes a recognized tool to investigate ecotoxicity of nanoparticles [33]. No visible precipitate was observed during the test over the two months period, which confirmed nanoparticles suspension stability. Our results showed EC50 values of respectively $43.75 \pm 23.38 \mathrm{mg} \cdot \mathrm{L}^{-1}$ and $36.51 \pm 20.55 \mathrm{mg} \cdot \mathrm{L}^{-1}$ at $5 \mathrm{~min}$ and $15 \mathrm{~min}$. The calculated EC50 after 5 and $15 \mathrm{mi}-$ nutes exposure time are quite similar. The slight decrease could mean that the nanoparticles need a short time to diffuse into the cells and interact with lipids, carbohydrates, proteins and DNA [34]. Obtained EC50 values for $\mathrm{TiO}_{2}$ particles are much higher, relative to the literature [35] [36]. This may be due to our particular and original way of synthesis of nanoparticles with the use of acetylacetone which is known as a toxic molecule [37]. Our $\mathrm{TiO}_{2}$ nanoparticles with EC50 ranging from 36 to $44 \mathrm{mg} \cdot \mathrm{L}^{-1}$, can be classified as harmful to aquatic micro-organisms (EC50 in the range of $10-100 \mathrm{mg} \cdot \mathrm{L}^{-1}$ ) according to the Commission Directive 93/67/EEC from the European Union for the assessment of risk to man and the environment of substances.

We have demonstrated the toxicity of our nanoparticle suspension in the dark on a very sensitive bacterium, Vibrio fischeri.

\subsection{Inactivation Kinetics Measurements}

As in previous studies on Escherichia coli LE392 [38] where we clearly observed the total destruction of bacteria

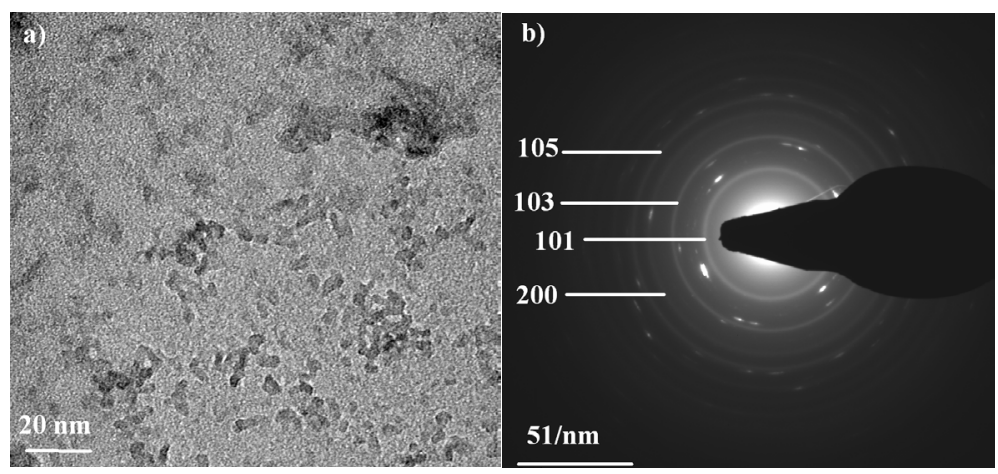

Figure 2. TEM image of $\mathrm{TiO}_{2}$ nanoparticles (a) and SAED pattern of the particles (b).

Table 1. Interplanar distances for the $\mathrm{TiO}_{2}$ nanoparticles deduced from the SAED patterns, compared to the expected ones for ideal anatase phase.

\begin{tabular}{cccccc}
\hline Interplanar distance from the SAED pattern $(\AA)$ & 3.57 & 2.41 & 1.93 & 1.70 \\
Theoretical distance for the anatase phase $(\AA)$ & 3.51 & 2.33 & 1.89 & 1.66 \\
Corresponding Miller indice & $(101)$ & $(103)$ & $(200)$ & $(211)$ \\
\hline
\end{tabular}


after only 1 hour of treatment with $1 \mathrm{~g} \cdot \mathrm{L}^{-1} \mathrm{TiO}_{2}$ suspension under UV irradiation, we could wonder what happens during this time duration. Figure 3 shows that after $10 \mathrm{~min}$ of treatment, approximately $40 \%$ of bacteria tested (E. coli LE392 and ETEC H10407) died. Ten minutes later, we can observe a drastic diminution of the population with around $80 \%$ of mortality. Finally, under these particular conditions, we clearly observed the total destruction of both strains of bacteria after only 30 minutes.

Freshly grown bacterial cultures $\left(10^{6} \mathrm{CFU} \cdot \mathrm{mL}^{-1}\right)$ were treated with $1 \mathrm{~g} \cdot \mathrm{L}^{-1}$ of $\mathrm{TiO}_{2}$ and irradiated with UV $\left(1.5 \mathrm{~mW} \cdot \mathrm{cm}^{-2}\right)$. This experiment was carried out in triplicate. Wang et al. [39] found quite similar results showing that a lower $\mathrm{TiO}_{2}$ nanoparticles concentration $\left(0.4 \mathrm{~g} \cdot \mathrm{L}^{-1}\right)$ had a similar inactivation effect on $E$. coli but after $2 \mathrm{~h}$ UVA irradiation.

\section{5. $\mathrm{TiO}_{2}$ Suspension Phototoxicity against Bacteria}

The 30 minutes-LC50 tests were then performed on all strains in order to make a comparison between bacteria differing in cell wall structure and detoxification system implicating the catalase enzyme (Table 2).

Concentration-dependent mortality in E. coli exposed to $\mathrm{TiO}_{2}$ suspension under 30 minutes UV irradiation $\left(1.5 \mathrm{~mW} \cdot \mathrm{cm}^{-2}\right)$ showed a linear profile for both strains at a concentration ranging from 100 to $600 \mathrm{mg} \cdot \mathrm{L}^{-1}$ (Figure 4). The LC50 calculated by linear regression were $340 \mathrm{mg} \cdot \mathrm{L}^{-1}$ for LE392 and $281 \mathrm{mg} \cdot \mathrm{L}^{-1}$ for ETEC $\mathrm{H} 10407$ (Table 2). The $\mathrm{TiO}_{2}$ nanoparticles suspension had differing inactivation efficiency regarding Lactobacillus casei rhamnosus and Staphylococcus aureus. LC50 was calculated to be $195 \mathrm{mg} \cdot \mathrm{L}^{-1}$ for $L$. casei rhamnosus $35^{\circledR}$ whereas the value of $585 \mathrm{mg} \cdot \mathrm{L}^{-1}$ was determinated for $S$. aureus. We can observe that concentration-dependent survival is higher for the $S$. aureus gram-positive catalase-positive bacteria compared to the other ones.

The fact that $\mathrm{TiO}_{2}$ nanoparticles showed a lower effect on $S$. aureus than on the other ones, under the same conditions, indicates that the resistance of bacteria to $\mathrm{TiO}_{2}$ nanoparticles is species-dependent. These differences might be due to different structural properties of cell wall and/or a higher self-defense property [40] or self-repair ability of $S$. aureus than the other ones. Only focusing on the cell wall property of bacteria tested, we can see that the more resistant one is $S$. aureus which has a gram-positive cell wall. This is in accordance with previous

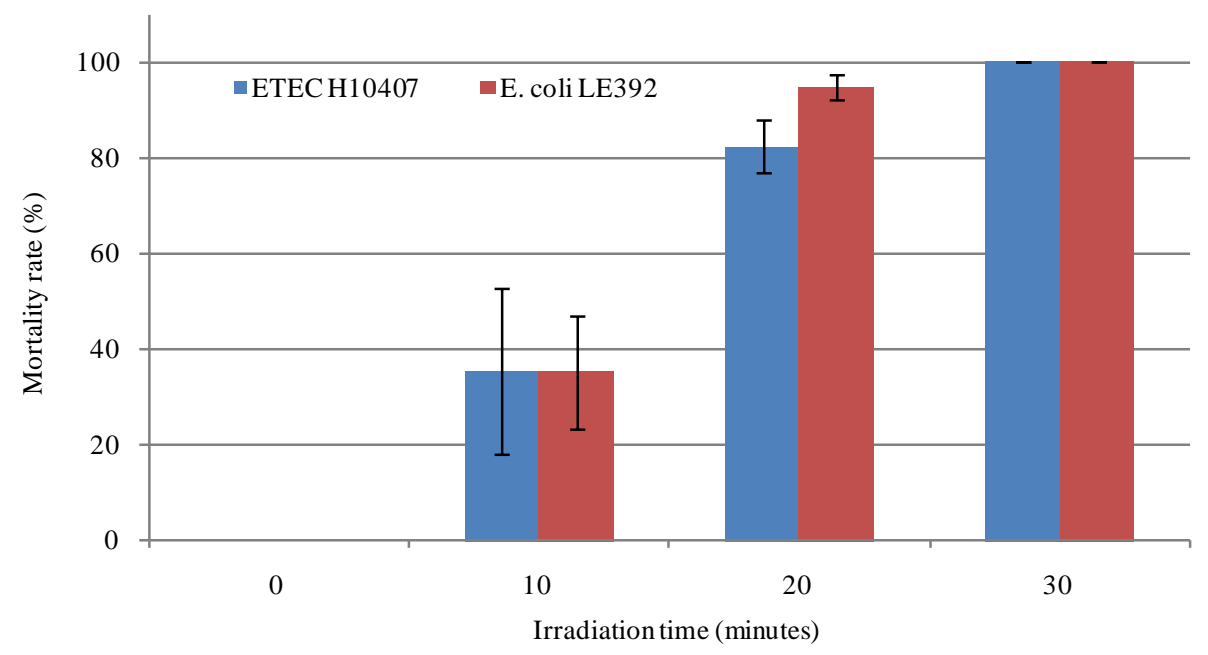

Figure 3. Influence of irradiation time on the mortality rate of Escherichia coli LE392 and Enterotoxigenic Escherichia coli H10407.

Table 2. Wall type and catalase activity of different tested bacteria strains.

\begin{tabular}{clcc}
\hline Bacteria & Gram & Catalase & LC50 $\left(\mathrm{mg} \cdot \mathrm{L}^{-1}\right)$ \\
\hline E. coli LE392 & negative & positive & 340 \\
Enterotoxigenic E. coli & negative & positive & 281 \\
L. casei rhamnosus & positive & negative & 195 \\
S. aureus & positive & positive & 585 \\
\hline
\end{tabular}




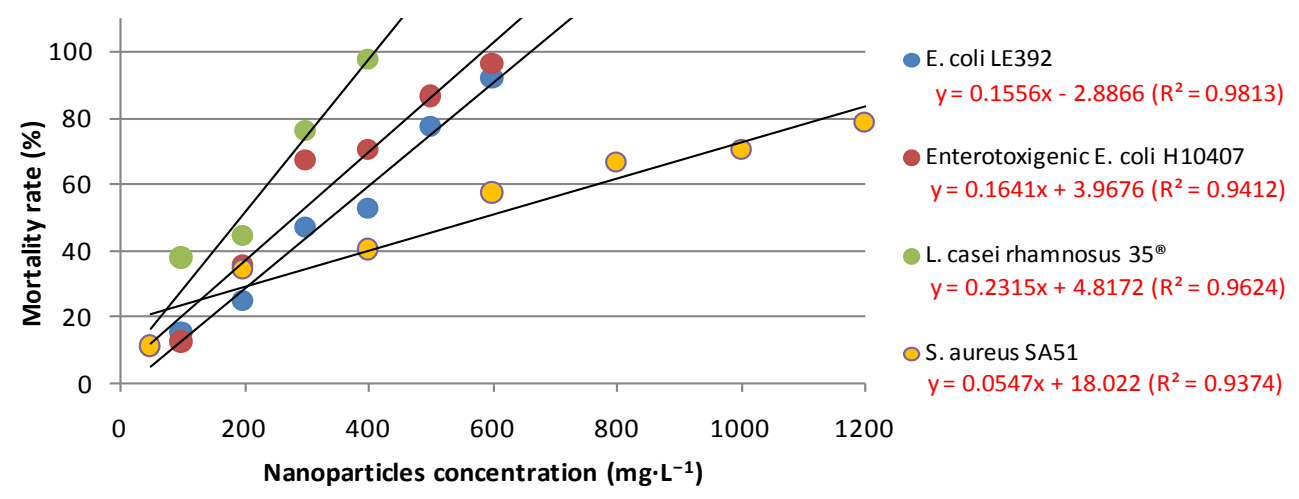

Figure 4. Determination of LC50 for Escherichia coli LE392, Enterotoxigenic Escherichia coli H10407, Lactobacillus casei rhamnosus Lcr35 ${ }^{\circledR}$ and Staphylococcus aureus SA51 when exposed to $\mathrm{TiO}_{2}$ nanoparticles with concentrations ranging from 50 to $1200 \mathrm{mg} \cdot \mathrm{L}^{-1}$ under $30 \mathrm{~min} \mathrm{UV}$ irradiation at $1.5 \mathrm{~mW} \cdot \mathrm{cm}^{-2}$. Experiments were carried out in triplicate. $\mathrm{R}^{2}$ is a measure of goodness-of-fit of linear regression.

results [41] [42] respectively using $\mathrm{ZnO}$ and Ag nanoparticles, which exhibited a much stronger antibacterial effect on gram-negative bacteria. This difference in antimicrobial activity between gram-positive and gramnegative micro-organisms is often attributed to the structure of their perspective cell walls [43]. On the other hand, our results are not similar with another report using $\mathrm{ZnO}$ nanoparticles that showed a much stronger antibacterial effect on gram-positive bacteria than on gram-negative ones [44]-[46]. In addition, van Grieken et al. [47] observed no significant differences between the photocatalytic inactivation of gram-negative and grampositive bacteria for all experiments and concluded that despite their differences in cell wall structure, both $E$. coli and E. faecalis showed similar reaction to the treatment. Moreover, in our study, the most sensitive bacterium is Lcr $35^{\circledR}$ even if this micro-organism belongs to the gram-positive bacteria class. All these results confirm that the cell wall structure is not the primary factor involved in resistance to nanoparticles.

Major constituents of the cell wall are each specific strains and the surface charge of the bacteria is associated with the presence of the ionized groups of the macromolecules [48]. Generally, the cell wall of gram-positive bacteria has a stronger negative charge than gram-negative bacteria. This negative charge is due to the presence of teichoic acid in gram-positive bacteria and lipophosphate in gram-negative ones [49].

There are reports in the literature that show that electrostatic attraction between negatively charged bacterial cells and positively charged nanoparticles is crucial for the activity of nanoparticles as bactericidal materials. Nanoparticles are capable of penetrating bacterial cells and act as a catalyst, to inactivate enzymes that microorganisms need for their metabolism by interacting with thiol groups of proteins, disrupt bacterial membranes and also affect DNA replication [50] [51]. In the case of nanoparticles of $\mathrm{TiO}_{2}$ illuminated with UV, the produced hydrogen peroxide will contribute to this phenomenon [52]. Marugán et al. [40] found that bacteria by themselves had self-protection ability and could grow again after being injured. Therefore, the inactivation of bacteria requires a certain amount of cumulative damage.

In our study, we have to take into account the presence or absence in cells of an enzyme responsible for catalyzing the breakdown of hydrogen peroxide into water and molecular oxygen: catalase [53] [54]. The highest resistance of $S$. aureus encountered here could be explained by the combination of its cell wall gram+ and the diminution of extracellular and/or intracellular $\mathrm{H}_{2} \mathrm{O}_{2}$ concentration by catalase.

\section{6. $\mathrm{H}_{2} \mathrm{O}_{2}$ Measurements}

$\mathrm{TiO}_{2}$ is a semiconductor [55] which can be excited by UV light. In these conditions, an electron of $\mathrm{TiO}_{2}$ receives photon energy and is excited [56]. It then reacts with $\mathrm{H}_{2} \mathrm{O}$ and/or $\mathrm{O}_{2}$ and produces hydroxyl radicals and/or active oxygen species [57]. The active species further react with bacteria and inactivate them. The damage cannot be completed in a short time, even though there are enough radicals produced by photocatalytic nano- $\mathrm{TiO}_{2}[39]$.

With the aim of evaluating the $\mathrm{H}_{2} \mathrm{O}_{2}$ production capacity by $\mathrm{TiO}_{2}$ nanoparticles in the dark or under UV irradiation after 30 minutes, we measured concentration of this molecule with regard with different nanoparticles concentrations ( 0 from $1200 \mathrm{mg} \cdot \mathrm{L}^{-1}$, Figure 5). The influence of the presence of bacteria on this parameter was also evaluated. 


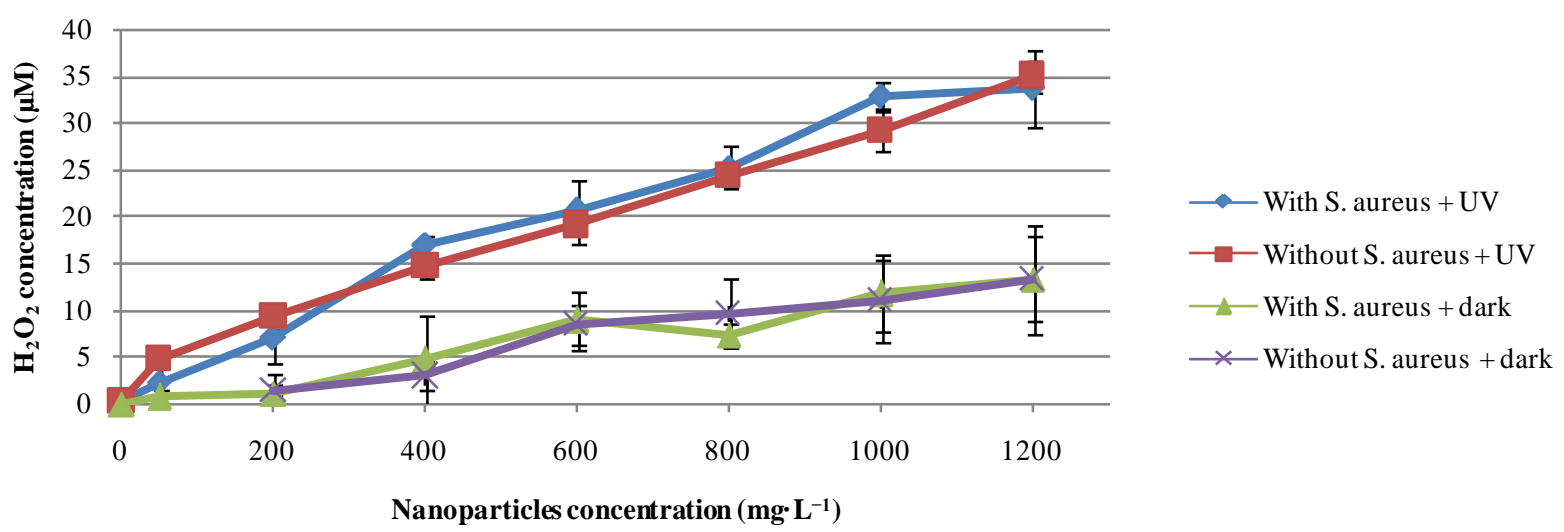

Figure 5. Influence of Staphylococcus aureus on the concentration of hydrogen peroxide $\left(\mathrm{mg} \cdot \mathrm{L}^{-1}\right)$ after 30 minutes in the dark or under UV irradiation, for different nanoparticles concentrations. Experiment was carried out in triplicate.

For this experiment, we chose $S$. aureus because it was the most resistant bacterium among the four tested. Its resistance may be due to a detoxification capacity of the external environment by a catalase activity. Effectively, in order to counteract excess ROS, various antioxidant mechanisms are activated in the organisms. The initial mechanisms that act to adjust antioxidant levels to protect the cells include changes in antioxidant gene expression [58].

We observed (Figure 5) that in the dark the presence of $\mathrm{H}_{2} \mathrm{O}_{2}$ was proportional to $\mathrm{TiO}_{2}$ concentration. The maximum value obtained was $13.23 \pm 4.49 \mu \mathrm{mol} \cdot \mathrm{L}^{-1}$ with $1200 \mathrm{mg} \cdot \mathrm{L}^{-1}$ of nanoparticles in presence of $S$. $a u-$ reus. This result shows that even in the dark, the $\mathrm{TiO}_{2}$ nanoparticles cause the synthesis of hydrogen peroxide. Several studies indicate that certain nanomaterials, including metal oxide nanoparticles, have the potential to exhibit spontaneous ROS production based on material composition and surface characteristics [59]-[61]. The presence of $S$. aureus did not significantly affect this content. Under these conditions, it was not possible to show a detoxifying activity, by the micro-organism, in its environment.

Under UV irradiation, $\mathrm{H}_{2} \mathrm{O}_{2}$ concentration obtained was significantly greater than in dark condition. The maximum concentration (35 $\pm 1.66 \mu \mathrm{M}$ hydrogen peroxide) was achieved with $1200 \mathrm{mg} \cdot \mathrm{L}^{-1}$ of nanoparticles without $S$. aureus. As in the dark condition, the bacteria did not change the content of $\mathrm{H}_{2} \mathrm{O}_{2}$ in their extracellular environment.

The greatest resistance of $S$. aureus to $\mathrm{TiO}_{2}$ nanoparticles under UV irradiation is probably due to an intracellular detoxification process and wall thickness properties.

\section{Conclusion}

In this study, we synthesized stable anatase titanium dioxide nanoparticles in suspension. We evaluated the environmental toxicity of suspension using Microtox ${ }^{\circledR}$ test. The Microtox ${ }^{\circledR}$ test using Vibrio fischeri has classified our nanoparticles as harmful to aquatic micro-organisms. The hydrogen peroxide quantification indicated that $\mathrm{H}_{2} \mathrm{O}_{2}$ was involved in the biological mechanism. The comparison between the bacteria strains showed a higher resistance with S. aureus than with E. coli and Lcr35 ${ }^{\circledR}$. This resistance may be due to the presence of the catalase gene in its genome and its thicker wall.

However, further studies are needed in order to elucidate mechanisms of toxicity induced by our $\mathrm{TiO}_{2}$ nanoparticles, so it could be interesting to determine intracellular ROS concentration, lipid peroxidation level, membrane integrity and DNA damage. Gene expression analysis by RT-qPCR and/or RNA-Seq will also permit us to assess all the effects of our nanoparticles on the different metabolic pathways and especially on the oxidative pathway.

\section{Acknowledgements}

The authors acknowledge the University of Auvergne for its financial support and the company Probionov for the gift of Lactobacillus casei rhamnosus Lcr35 ${ }^{\circledR}$ and Enterotoxigenic E. coli H10407. The authors acknowledge Yves Sibaud and Michelle Conry for their technical support. 


\section{References}

[1] Backer, L.C., Ashley, D.L., Bonin, M.A., Cardinali, F.L., Kieszak, S.M. and Wooten, J.V. (2000) Household Exposures to Drinking Water Disinfection By-Products: Whole Blood Trihalomethane Levels. Journal of Exposure Science and Environmental Epidemiology, 10, 321-326. http://dx.doi.org/10.1038/sj.jea.7500098

[2] Batterman, S., Zhang, L.Z. and Wang, S.Q. (2000) Quenching of Chlorination Disinfection By-Product Formation in Drinking Water by Hydrogen Peroxide. Water Research, 34, 1652-1658. http://dx.doi.org/10.1016/S0043-1354(99)00294-8

[3] Miltner, R.J., Shukairy, H.M. and Summers, R.S. (1992) Disinfection By-Product Formation and Control by Ozonation and Biotreatment. Journal of the American Water Works Association, 84, 53-62.

[4] von Gunten, U. (2003) Ozonation of Drinking Water: Part II. Disinfection and By-Product Formation in Presence of Bromide, Iodide or Chlorine. Water Research, 37, 1469-1487. http://dx.doi.org/10.1016/S0043-1354(02)00458-X

[5] Hammes, F., Salhi, E., Köster, O., Kaiser, H.P., Egli, T. and von Gunten, U. (2006) Mechanistic and Kinetic Evaluation of Organic Disinfection By-Product and Assimilable Organic Carbon (AOC) Formation during the Ozonation of Drinking Water. Water Research, 40, 2275-2286. http://dx.doi.org/10.1016/j.watres.2006.04.029

[6] Sunada, K., Watanabe, T. and Hashimoto, K. (2003) Studies on Photokilling of Bacteria on $\mathrm{TiO}_{2}$ Thin Film. Journal of Photochemistry and Photobiology A: Chemistry, 156, 227-233. http://dx.doi.org/10.1016/S1010-6030(02)00434-3

[7] Tsuang, Y.H., Sun, J.S., Huang, Y.C., Lu, C.H., Chang, W.H.S. and Wang, C.C. (2008) Studies of Photokilling of Bacteria Using Titanium Dioxide Nanoparticles. Artificial Organs, 32, 167-174. http://dx.doi.org/10.1111/j.1525-1594.2007.00530.x

[8] Guan, K.S. (2005) Relationship between Photocatalytic Activity, Hydrophilicity and Self-Cleaning Effect of TiO ${ }_{2} /$ $\mathrm{SiO}_{2}$ Films. Surface and Coatings Technology, 191, 155-160. http://dx.doi.org/10.1016/j.surfcoat.2004.02.022

[9] Mellott, N., Durucan, C., Pantano, C. and Guglielmi, M. (2006) Commercial and Laboratory Prepared Titanium Dioxide Thin Films for Self-Cleaning Glasses: Photocatalytic Performance and Chemical Durability. Thin Solid Films, 502, 112-120. http://dx.doi.org/10.1016/j.tsf.2005.07.255

[10] Guan, H.M., Zhu, L.H., Zhou, H.H. and Tang, H.Q. (2008) Rapid Probing of Photocatalytic Activity on Titania-Based Self-Cleaning Materials Using 7-Hydroxycoumarin Fluorescent Probe. Analytica Chimica Acta, 608, 73-78. http://dx.doi.org/10.1016/j.aca.2007.12.009

[11] Wu, D., Long, M., Zhou, J., Cai, W., Zhu, X., Chen, C. and Wu, Y. (2009) Synthesis and Characterization of SelfCleaning Cotton Fabrics Modified by $\mathrm{TiO}_{2}$ through a Facile Approach. Surface and Coatings Technology, 203, 37283733. http://dx.doi.org/10.1016/j.surfcoat.2009.06.008

[12] Chen, W.J., Tsai, P.J. and Chen, Y.C. (2008) Functional $\mathrm{Fe}_{3} \mathrm{O}_{4} / \mathrm{TiO}_{2}$ Core/Shell Magnetic Nanoparticles as PhotoKilling Agents for Pathogenic Bacteria. Small, 4, 485-491. http://dx.doi.org/10.1002/smll.200701164

[13] Choi, J.Y., Kim, K.H., Choy, K.C., Oh, K.T. and Kim, K.N. (2007) Photocatalytic Antibacterial Effect of TiO ${ }_{2}$ Film Formed on Ti and TiAg Exposed to Lactobacillus acidophilus. Journal of Biomedical Materials Research Part B: Applied Biomaterials, 80, 353-359. http://dx.doi.org/10.1002/jbm.b.30604

[14] Kubacka, A., Ferrer, M., Martnez-Arias, A. and Fernández-Garca, M. (2008) Ag Promotion of TiO ${ }_{2}$-Anatase Disinfection Capability: Study of Escherichia coli Inactivation. Applied Catalysis B: Environmental, 84, 87-93.

[15] Kahru, A., Tomson, K., Pall, T. and Külm, I. (1996) Study of Toxicity of Pesticides Using Luminescent Bacteria Photobacterium phosphoreum. Water Science and Technology, 33, 147-154. http://dx.doi.org/10.1016/0273-1223(96)00292-2

[16] Barrena, R., Casals, E., Colon, J., Font, X., Sanchez, A. and Puntes, V. (2009) Evaluation of the Ecotoxicity of Model Nanoparticles. Chemosphere, 75, 850-857. http://dx.doi.org/10.1016/j.chemosphere.2009.01.078

[17] Cai, R., Kubota, Y., Shuin, T., Sakai, H., Hashimoto, K. and Fujishima, A. (1992) Induction of Cytotoxicity by Photoexcited $\mathrm{TiO}_{2}$ Particles. Cancer Research, 52, 2346-2348.

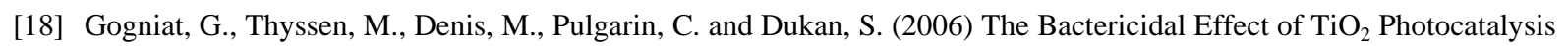
Involves Adsorption onto Catalyst and the Loss of Membrane Integrity. FEMS Microbiology Letters, 258, 18-24. http://dx.doi.org/10.1111/j.1574-6968.2006.00190.x

[19] Jang, H.D., Kim, S.K. and Kim, S.J. (2001) Effect of Particle Size and Phase Composition of Titanium Dioxide Nanoparticles on the Photocatalytic Properties. Journal of Nanoparticle Research, 3, 141-147. http://dx.doi.org/10.1023/A:1017948330363

[20] Braydich-Stolle, L.K., Schaeublin, N.M., Murdock, R.C., Jiang, J., Biswas, P., Schlager, J.J. and Hussain, S.M. (2009) Crystal Structure Mediates Mode of Cell Death in $\mathrm{TiO}_{2}$ Nanotoxicity. Journal of Nanoparticles Research, 11, 13611374. http://dx.doi.org/10.1007/s11051-008-9523-8 
[21] Xia, T., Kovochich, M., Brant, J., Hotze, M., Sempf, J. and Oberley, T. (2006) Comparison of the Abilities of Ambient and Manufactured Nanoparticles to Induce Cellular Toxicity According to an Oxidative Stress Paradigm. Nano Letters, 6, 1794-1807. http://dx.doi.org/10.1021/nl061025k

[22] Singh, N., Manshian, B., Jenkins, G.J.S., Griffiths, S.M., Williams, P.M., Maffeis, T.G.G., Wright, C.J. and Doak, S.H. (2009) NanoGenotoxicology: The DNA Damaging Potential of Engineered Nanomaterials. Biomaterials, 30, 38913914. http://dx.doi.org/10.1016/j.biomaterials.2009.04.009

[23] Gou, N. and Gu, A.Z. (2011) A New Transcriptional Effect Level Index (TELI) for Toxicogenomics-Based Toxicity Assessment. Environmental Science and Technology, 45, 5410-5417. http://dx.doi.org/10.1021/es200455p

[24] Hu, C., Lan, Y.Q., Qu, J.H., Hu, X.X. and Wang, A.M. (2006) Ag/AgBr/TiO 2 Visible Light Photocatalyst for Destruction of Azodyes and Bacteria. Journal of Physical Chemistry B, 110, 4066-4072. http://dx.doi.org/10.1021/jp0564400

[25] Unfried, K., Albrecht, C., Klotz, L.O., Von Mikecz, A., Grether-Beck, S. and Schins, R.P.F. (2007) Cellular Responses to Nanoparticles: Target Structures and Mechanisms. Nanotoxicology, 1, 52-71. http://dx.doi.org/10.1080/00222930701314932

[26] Verma, A., Uzun, O., Hu, Y., Hu, Y., Han, H.S., Watson, N., Chen, S., Irvine, D.J. and Stellacci, F. (2008) SurfaceStructure-Regulated Cell-Membrane Penetration by Monolayer-Protected Nanoparticles. Nature Materials, 7, 588-595. http://dx.doi.org/10.1038/nmat2202

[27] Nel, A.E., Mädler, L., Velegol, D., Xia, T., Hoek, E.M.V., Somasundaran, P., Klaessig, F., Castranova, V. and Thompson, M. (2009) Understanding Biophysicochemical Interactions at the Nano-Bio Interface. Nature Materials, 8, 543-557. http://dx.doi.org/10.1038/nmat2442

[28] Verma, A. and Stellacci, F. (2010) Effect of Surface Properties on Nanoparticle Cell Interactions. Small, 6, $12-21$. http://dx.doi.org/10.1002/smll.200901158

[29] Chance, B., Sies, H. and Boveris, A. (1979) Hydroperoxide Metabolism in Mammalian Organs. Physiological Reviews, 59, 527-605.

[30] Goodhew, P.J. and Humphrey, F.J. (1988) Electron Microscopy and Analysis. Taylor and Francis Inc., Philadelphia.

[31] Batdorj, B., Trinetta, V., Dalgalarrondo, M., Prevost, H., Dousset, X., Ivanova, I., Haertle, T. and Chobert, J.M. (2007) Isolation, Taxonomic Identification and Hydrogen Peroxide Production by Lactobacillus delbrueckii subsp. Lactis T31, Isolated from Mongolian Yoghurt: Inhibitory Activity on Food-Borne Pathogens. Journal of Applied Microbiology, 103, 584-593. http://dx.doi.org/10.1111/j.1365-2672.2007.03279.x

[32] Parvez, S., Venkataraman, C. and Mukherji, S. (2006) A Review on Advantages of Implementing Luminescence Inhibition Test (Vibrio fischeri) for Acute Toxicity Prediction of Chemicals. Environment International, 32, 265-268. http://dx.doi.org/10.1016/j.envint.2005.08.022

[33] Kahru, A., Dubourguier, H.C., Blinova, I., Ivask, A. and Kasemets, K. (2008) Biotests and Biosensors for Ecotoxicology of Metal Oxide Nanoparticles: A Minireview. Sensors, 8, 5153-5170. http://dx.doi.org/10.3390/s8085153

[34] Binaeian, E., Rashidi, A.M. and Attar, H. (2012) Toxicity Study of Two Different Synthesized Silver Nanoparticles on Bacteria Vibrio fischeri. World Academy of Science, Engineering and Technology, 67, 1219-1225.

[35] Garcia, A., Espinosa, R., Delgado, L., Casals, E., Gonzalez, E., Puntes, V., Barata, C., Font, X. and Sanchez, A. (2011) Acute Toxicity of Cerium Oxide and Iron Oxide Nanoparticles Using Standardized Tests. Desalination, 269, 136-141. http://dx.doi.org/10.1016/j.desal.2010.10.052

[36] Lopes, I., Ribeiro, R., Antunes, F.E., Rocha-Santos, T.A., Rasteiro, M.G., Soares, A.M., Gonçalves, F. and Pereira, R. (2012) Toxicity and Genotoxicity of Organic and Inorganic Nanoparticles to the Bacteria Vibrio fischeri and Salmonella typhimurium. Ecotoxicology, 21, 637-648. http://dx.doi.org/10.1007/s10646-011-0808-9

[37] Straganz, G.D., Glieder, A., Brecker, L., Ribbons, D.W. and Steiner, W. (2003) Acetylacetone-Cleaving Enzyme Dke1: A Novel C-C-Bond-Cleaving Enzyme from Acinetobacter johnsonii. Biochemistry Journal, 369, 573-581. http://dx.doi.org/10.1042/BJ20021047

[38] Massard, C., Bonnet, M., Veisseire, P., Sibaud, Y., Caudron, E. and Awitor, K.O. (2013) Photokilling of Escherichia coli Using Hybrid Titania Nanoparticles Suspended in an Aqueous Liquid. Journal of Biomaterials and Nanobiotechnology, 4,137-144. http://dx.doi.org/10.4236/jbnb.2013.42019

[39] Wang, J., Li, C., Zhuang, H. and Zhang, J. (2013) Photocatalytic Degradation of Methylene Blue and Inactivation of Gram-Negative Bacteria by $\mathrm{TiO}_{2}$ Nanoparticles in Aqueous Suspension. Food Control, 34, 372-377. http://dx.doi.org/10.1016/j.foodcont.2013.04.046

[40] Marugán, J., van Grieken, R., Sordo, C. and Cruz, C. (2008) Kinetics of the Photocatalytic Disinfection of Escherichia coli Suspensions. Applied Catalysis B: Environmental, 82, 27-36. http://dx.doi.org/10.1016/j.apcatb.2008.01.002

[41] Nair, S., Sasidharan, A., Rani, V.V.D., Menon, D., Nair, S. and Manzoor, K. (2009) Role of Size Scale of ZnO Nanoparticles and Microparticles on Toxicity toward Bacteria and Osteoblast Cancer Cells. Journal of Materials Science: 
Materials in Medicine, 20, 235-241. http://dx.doi.org/10.1007/s10856-008-3548-5

[42] Tamboli, D.P. and Lee, D.S. (2013) Mechanistic Antimicrobial Approach of Extracellularly Synthesized Silver Nanoparticles against Gram Positive and Gram Negative Bacteria. Journal of Hazardous Materials, 260, 878-884. http://dx.doi.org/10.1016/j.jhazmat.2013.06.003

[43] Shrivastava, S., Bera, T., Roy, A., Singh, G., Ramachandrarao, P. and Dash, D. (2007) Characterization of Enhanced Antibacterial Effects of Novel Silver Nanoparticles. Nanotechnology, 18, 103-112.

[44] Premanathan, M., Karthikeyan, K., Jeyasubramanian, K. and Manivannan, G. (2011) Selective Toxicity of ZnO Nanoparticles toward Gram-Positive Bacteria and Cancer Cells by Apoptosis through Lipid Peroxidation. Nanomedicine: Nanotechnology, Biology and Medicine, 7, 184-192. http://dx.doi.org/10.1016/j.nano.2010.10.001

[45] Yadav, H.M., Otari, S.V., Koli, V.B., Mali, S.S., Hong, C.K., Pawar, S.H. and Delekar, S.D. (2014) Preparation and Characterization of Copper-Doped Anatase $\mathrm{TiO}_{2}$ Nanoparticles with Visible Light Photocatalytic Antibacterial Activity. Journal of Photochemistry and Photobiology A: Chemistry, 280, 32-38. http://dx.doi.org/10.1016/j.jphotochem.2014.02.006

[46] Yadav, H.M., Otari, S.V., Bohara, R.A., Mali, S.S., Pawar, S.H. and Delekar, S.D. (2014) Synthesis and Visible Light Photocatalytic Antibacterial Activity of Nickel-Doped Nanoparticles against Gram-Positive and Gram-Negative Bacteria. Journal of Photochemistry and Photobiology A: Chemistry, 294, 130-136. http://dx.doi.org/10.1016/j.jphotochem.2014.07.024

[47] van Grieken, R., Marugán, J., Pablos, C., Furones, L. and López, A. (2010) Comparison between the Photocatalytic Inactivation of Gram-Positive E. faecalis and Gram Negative E. coli Faecal Contamination Indicator Microorganisms. Applied Catalysis B: Environmental, 100, 212-220. http://dx.doi.org/10.1016/j.apcatb.2010.07.034

[48] Rijnaarts, H.H.M., Norde, W., Lyklema, J. and Zehnder, A. (1995) The Isoelectric Point of Bacteria as an Indicator for the Presence of Cell Surface Polymers That Inhibit Adhesion. Colloid Surface B, 4, 191-197. http://dx.doi.org/10.1016/0927-7765(94)01164-Z

[49] Juang, D.F., Yang, P.C., Lee, C.H., Hsueh, S.C. and Kuo, T.H. (2011) Electrogenic Capabilities of Gram Negative and Gram Positive Bacteria in Microbial Fuel Cell Combined with Biological Wastewater Treatment. International Journal of Environmental Science and Technology, 8, 781-792. http://dx.doi.org/10.1007/BF03326261

[50] Klaine, S.J., Alvarez, P.J.J., Batley, G.E., Fernandes, T.F., Hande, R.D., Lyon, D.Y., Mahendra, S., McLaughlin, M.J. and Lead, J.R. (2008) Nanomaterials in the Environment: Behavior, Fate, Bioavailability, and Effects. Environmental Toxicology and Chemistry, 27, 1825-1851. http://dx.doi.org/10.1897/08-090.1

[51] Pelletier, D.A., Suresh, A.K., Holton, G.A., McKeown, C.K., Wang, W., Gu, B., Mortensen, N.P., Allison, D.P., Joy, D.C., Allison, M.R., Brown, S.D., Phelps, T.J. and Doktycz, M.J. (2010) Effects of Engineered Cerium Oxide Nanoparticles on Bacterial Growth and Viability. Applied and Environmental Microbiology, 76, 7981-7989. http://dx.doi.org/10.1128/AEM.00650-10

[52] Bartoli, M. and Dusseau, J.Y. (1995) Oxydants. In: Fleurette, J., Fresney, J. and Reverdy, M.E., Eds., Antiseptie et désinfection, Editions Eska, Paris, 305-314.

[53] Hamouda, T. and Baker Jr., J.R. (2000) Antimicrobial Mechanism of Action of Surfactant Lipid Preparations in Enteric Gram-Negative Bacilli. Journal of Applied Microbiology, 89, 397-403. http://dx.doi.org/10.1046/j.1365-2672.2000.01127.x

[54] Sondi, I. and Salopek-Sondi, B. (2004) Silver Nanoparticles as Antimicrobial Agent: A Case Study on E. coli as a Model for Gram-Negative Bacteria. Journal of Colloid and Interface Science, 275, 177-182. http://dx.doi.org/10.1016/j.jcis.2004.02.012

[55] Fujishima, A. and Honda, K. (1972) Electrochemical Photocatalysis of Water at a Semiconductor Electrode. Nature, 238, 37-38. http://dx.doi.org/10.1038/238037a0

[56] Carp, O., Huisman, C.L. and Reller, A. (2004) Photoinduced Reactivity of Titanium Dioxide. Progress in Solid State Chemistry, 32, 33-177. http://dx.doi.org/10.1016/j.progsolidstchem.2004.08.001

[57] Liu, H. and Yang, T.C. (2003) Photocatalytic Inactivation of Escherichia coli and Lactobacillus helveticus by ZnO and $\mathrm{TiO}_{2}$ Activated with Ultraviolet Light. Process Biochemistry, 39, 475-481. http://dx.doi.org/10.1016/S0032-9592(03)00084-0

[58] Cushman, J.C. and Bohnert, H.J. (2000) Genomic Approaches to Plant Stress Tolerance. Current Opinion in Plant Biology, 3, 117-124. http://dx.doi.org/10.1016/S1369-5266(99)00052-7

[59] Lovric, J., Cho, S.J., Winnik, F.M. and Maysinger, D. (2005) Unmodified Cadmium Telluride Quantum Dots Induce Reactive Oxygen Species Formation Leading to Multiple Organelle Damage and Cell Death. Chemistry and Biology, 12, 1227-1234. http://dx.doi.org/10.1016/j.chembiol.2005.09.008

[60] Long, T.C., Saleh, N., Tilton, R.D., Lowry, G.V. and Veronesi, B. (2006) Titanium Dioxide (P25) Produces Reactive Oxygen Species in Immortalized Brain Microglia (BV2): Implications for Nanoparticle Neurotoxicity. Environmental 
Science and Technology, 40, 4346-4352. http://dx.doi.org/10.1021/es060589n

[61] Kumar, A., Pandey, A.K., Singh, S.S., Shanker, R. and Dhawan, A. (2011) Engineered $\mathrm{ZnO}$ and $\mathrm{TiO}_{2} \mathrm{Nanoparticles}$ Induce Oxidative Stress and DNA Damage Leading to Reduced Viability of Escherichia coli. Free Radical Biology and Medicine, 51, 1872-1881. http://dx.doi.org/10.1016/j.freeradbiomed.2011.08.025 